\title{
PERLINDUNGAN HUKUM PERTANAHAN ADAT DI PAPUA DALAM NEGARA KESEJAHTERAAN
}

\author{
(Protection of Indigenous Land Law in Papua in the Welfare State)
}

\author{
Suharyo \\ Ahli Peneliti Utama pada Badan Penelitian dan Pengembangan Hukum dan HAM \\ JI H.R. Rasuna Said Kav. 4-5 Kuningan Jakarta 12920 \\ e-mail: suharyodenkes@gmail.com
}

Naskah diterima: 19 Agustus 2019; revisi: 4 November 2019; disetujui: 8 November 2019

\begin{abstract}
Abstrak
Perlindungan hukum setiap warga negara Republik Indonesia, telah ditegaskan dalam UUD 1945, utamanya setelah Perubahan Keempat pada Pasal 28A, 28B, 28C, 28D, 28E, 28G, 28H, 28I dan 28J, khusus dalam mewujudkan perlindungan masyarakat hukum adat diatur dalam Pasal 18B (2). Eksistensi masyarakat hukum adat di Papua berjumlah 200 suku, terbagi di dalam 7 (tujuh) wilayah adat, di antaranya wilayah adat I Mamta, wilayah adat II Sairei, wilayah adat III Bomberai, wilayah adat IV Bomberai, wilayah adat V Anim-Ha dan wilayah adat VII Mee Pago. Dengan diberlakukannya Undang-undang Nomor 21 Tahun 2001 Tentang Otonomi Khusus Provinsi Papua, yang mencakup Provinsi Papua dan Provinsi Papua Barat dan berbagai produk Perdasi serta Perdasus, sesungguhnya merupakan upaya kebijakan negara untuk mensejahterakan, menghormati dan melindungi masyarakat hukum adat di Papua. Permasalahannya adalah bagaimana kebijakan negara dalam mewujudkan perlindungan pertanahan adat di Papua dan bagaimana menciptakan situasi dan kondisi terbaik di tengah kendala yang ada. Metode yang dipakai adalah metode penelitian hukum normatif. Dari hasil analisis dapat ditarik kesimpulan sebagai berikut: perlindungan hukum pertanahan adat di Papua perlu dimaksimalkan. Sosialisasi Perdasus dan Perdasi serta konsistensi dalam pelaksanaannya, merupakan kebutuhan mendesak. Selain itu harmonisasi perundangundangan terkait, yaitu Undang-undang Nomor 41 Tahun 1999 tentang Kehutanan, dan Undang-undang Nomor 4 Tahun 2009 Tentang Pertambangan Mineral dan Batubara, yang tidak selaras dengan Undang-undang Nomor 21 Tahun 2001 Tentang Otonomi Khusus Provinsi Papua perlu dilakukan.
\end{abstract}

Kata Kunci: perlindungan hukum pertanahan adat Papua, kesejahteraan

\begin{abstract}
The legal protection of every citizen of the Republic of Indonesia has been affirmed in the 1945 Constitution, especially after the Fourth Amendment to Articles 28A, 28B, 28C, 28D, $28 \mathrm{E}, 28 \mathrm{G}, 28 \mathrm{H}, 28 \mathrm{I}, 28 \mathrm{~J}$, specifically in realizing the protection of customary law communities stipulated in Article 18B (2). There are 200 tribes of customary law communities in Papua which divided into 7 (seven) custom territories, including customary territory I Mamta, customary territory II Sairei, customary territory III Bomberai, customary territory IV Bomberai, customary territory V Anim-Ha, customary territory VII Mee Pago. With the enactment of the Law of the Republic Indonesia Number 21 Year 2001 on the Special Autonomy of the Province of Papua, which includes the Provinces of Papua, and the Province of West Papua and various Perdasi and Perdasus products, is actually an effort of state policy to prosper, respect and protect the customary law community in Papua. The problem is how the state policy in realizing the protection of custom land in Papua, and how to create the best situation and conditions in the midst of existing obstacles. The method used is a normative legal research method. From the analysis results it can be concluded that the following: the legal protection of customary land in Papua needs to be optimized. The socialization of Perdasus and Perdasi along with consistency in its implementation is an urgent need. In addition, harmonization of relevant legislation, namely the Law of the Republic Indonesia Number 41 of 1999 on Forestry, and the Law of the Republic Indonesia Number 4 of 2009 on Mineral and Coal Mining, which is not in line with the Law of the Republic Indonesia Number 21 Year 2001 on the Special Autonomy of the Province of Papua needs to be done.
\end{abstract}

Keywords: protection of indigenous land law in Papua, welfare 


\section{A. Pendahuluan}

Perlindungan hukum setiap warga negara Republik Indonesia, secara implisit dan eksplisit telah dinyatakan di dalam UUD 1945 dan lebih ditekankan lagi setelah Perubahan Keempat UUD 1945 di tahun 2002, terkait dengan aspek hak asasi manusia yang diatur pada pasal 28A, 28B, 28C, 28D, 28E, 28G, 28H, $28 \mathrm{I}$ dan 28J. Adapun yang tercantum dalam UUD 1945 tersebut, khususnya menyangkut perlindungan masyarakat hukum adat, diatur dalam Pasal 18B ayat (2), yang berbunyi: "negara mengakui dan menghormati kesatuankesatuan masyarakat hukum adat beserta hakhak tradisionalnya sepanjang masih hidup dan sesuai dengan perkembangan masyarakat dan prinsip Negara Kesatuan Republik Indonesia, yang diatur dalam undang-undang". ${ }^{1}$

Masyarakat Hukum Adat di Papua, termasuk di Papua Barat, terbagi di dalam 7 (tujuh) wilayah adat. Pertama, wilayah adat I Mamta di Kota Jayapura dengan 4 suku, Kabupaten Sarmi dengan 25 suku, Kabupaten Jayapura dengan 26 suku, Kabupaten Keeron dengan 14 suku dan Kabupaten Mamberamo 14 suku. Kedua, wilayah adat II Saireri: Kabupaten Biak 2 suku, Kabupaten Nabire 4 suku, Kabupaten Yapen 15 suku, Kabupaten Teluk Wondama 10 suku dan Kabupaten Waropen 10 suku. Ketiga, wilayah adat III Bomberai, Kabupaten Manokwari 6 suku, Kabupaten Raja Ampat 7 suku, Kabupaten Sorong 14 suku, Kabupaten Teluk Bintuni 7 suku, Kabupaten Sorong Selatan 6 suku. Keempat wilayah adat IV Bomberai, Kabupaten Fak-Fak 8 suku dan Kabupaten
Kaimana 8 suku. Kelima, wilayah adat V Anim$\mathrm{Ha}$, Kabupaten Merauke 8 suku, Kabupaten Boven Digul 10 suku, Kabupaten Asmat 7 suku, Kabupaten Mappi 4 suku. Keenam wilayah adat VI La Pago, Kabupaten Pegunungan Bintang 4 suku, KabupatenYahukimo 6 suku, Kabupaten Jayawijaya 4 suku dan Kabupaten Tolikara 5 suku. Ketujuh wilayah adat VII Mee Pago, Kabupaten Timika 3 suku, Kabupaten Puncak Jaya 6 suku dan Kabupaten Paniai 3 suku. $^{2}$

Sebagai daerah dengan luas 5 kali luas Pulau Jawa, dengan jumlah penduduk 3 juta jiwa, Provinsi Papua, dari berbagai aspek beserta kompleksitas permasalahan dan keunikan yang dimilikinya dan erlepas dari berbagai persoalan yang masih mengganjal, status Papua sebagai Daerah Otonomi Khusus perlu mendapat apresiasi positif. ${ }^{3}$ Melalui penerapan Undang-Undang Nomor 21 Tahun 2001 tentang Otonomi Khusus Papua, dengan peraturan pelaksanaannya yaitu Perdasi Papua Nomor 16 Tahun 2008.

Dinamika pembangunan ekonomi dan infrastruktur di Papua yang semakin meningkat yang dimaksudkan untuk mewujudkan kesejahteraan masyarakat, sekaligus meningkatkan ketertinggalan yang telah lama, yang pada gilirannya menimbulkan persoalan baru. Pembukaan lahan untuk perkebunan dan sarana serta prasarana lain, beririsan dengan kepentingan masyarakat adat di Papua. Prinsip-prinsip melalui produk perundang-undangan yang lain, ada yang berseberangan dengan upaya memberikan perlindungan pertanahan adat di Papua.

Undang-Undang Dasar Negara Republik Indonesia Tahun 1945.

Majelis Rakyat Papua (Jayapura, 2016).

H. Nuralam, Kesejahteraan Yang Tersandera: Implementasi Desentralisasi Fiskal dan Otonomi Khusus di Papua (Yogyakarta: Sonjana, 2011), hlm. 103. 
Antara pembangunan ekonomi dan perlindungan masyarakat hukum adat di Papua adalah suatu hubungan dalam artian menuju kesejahteraan yang senyatanya. Bahlil Hakadalia menyimpulkan tujuh hal penting dalam strategi pembangunan ekonomi Papua. Diantaranya, pertama, perekonomian Provinsi Papua yang merupakan bagian dari perekonomian nasional dan global, perlu diarahkan dan diupayakan untuk menciptakan sebesar-besarnya bagi kemakmuran dan kesejahteraan seluruh rakyat, dengan menjunjung tinggi prinsip keadilan pemerataan. Kedua, usaha-usaha pemanfaatan sumber daya alam dilakukan dengan tetap menghormati hak-hak masyarakat adat. ${ }^{4}$

Beranjak dari dilematis situasi dan kondisi masyarakat adat di Papua, dapat diidentifikasi suatu masalah; pertama, bagaimana kebijakan negara dalam mewujudkan perlindungan hukum pertanahan adat di Papua, yang kedua, bagaimana menciptakan situasi dan kondisi yang terbaik di tengah kendala-kendala yang ada, sebagai upaya menyelaraskan dengan tujuan negara kesejahteraan.

\section{B. Metode Penelitian}

Metode yang dipakai dalam penelitian hukum ini adalah penelitian hukum normatif. Suatu penelitian hukum normatif atau penelitian hukum kepustakaan adalah penelitian hukum yang dilakukan dengan cara meneliti bahan pustaka atau data sekunder. Penelitian hukum normatif atau kepustakaan tersebut mencakup penelitian terhadap asasasas hukum, penelitian terhadap sistematik hukum, penelitian terhadap taraf sinkronisasi vertikal dan horizontal, perbandingan hukum, dan sejarah hukum. ${ }^{5}$ Adapun bahan dan data-data tersebut, yang relevan dengan perlindungan hukum pertanahan adat di Papua, dan negara kesejahteraan.

\section{Pembahasan}

\section{Perlindungan Hukum Masyarakat dan Pertanahan Adat}

Upaya perlindungan hukum masyarakat hukum adat di Papua, dalam era reformasi dimulai dengan pembentukan Undangundang Nomor 21 Tahun 2001 tentang Otonomi Khusus di Papua. ${ }^{6}$ Secara mendasar otonomi khusus telah mengatur tentang berbagai aspek perlindungan masyarakat hukum adat. Dalam dasar Menimbang b. "bahwa masyarakat Papua sebagai insan ciptaan Tuhan dan bagian dari umat manusia yang beradab, menjunjung tinggi hak asasi manusia, nilai-nilai agama, demokrasi, hukum dan nilai-nilai budaya yang hidup dalam masyarakat hukum adat, serta memiliki hak untuk menikmati hasil pembangunan secara wajar".

Pada pasal 1 ayat (2) menegaskan bahwa "Masyarakat Hukum Adat adalah warga masyarakat asli Papua yang sejak kelahirannya hidup dalam wilayah tertentu dan terikat serta tunduk kepada hukum adat tertentu dengan rasa solidaritas yang tinggi diantara para anggotanya".

\footnotetext{
$4 \quad$ Velik V Wanggai, New Deal for Papua: Menata Kembali Papua Dengan Hati (Jakarta: Indonesia Press dan The Irian Institute, 2009), hlm 282-283.

5 Soerjono Soekanto dan Sri Mamudji, Penelitian Hukum Normatif: Suatu Tinjauan Singkat (Jakarta: Raja Grafindo Persada, 2001), hlm 13-14.

6 Lihat Undang-Undang Nomor 21 Tahun 2001 Tentang Otonomi Khusus di Papua.
} 
Pembentukan Majelis Rakyat Papua (MRP), merupakan langkah strategis dan konsisten dalam mewujudkan perlindungan masyarakat hukum adat di Papua. Pada pasal 19 ayat (1) "MRP beranggotakan orang-orang asli Papua yang terdiri atas wakil-wakil adat, wakil-wakil agama dan wakil-wakil perempuan yang jumlahnya masing-masing sepertiga dari total anggota MRP. Ayat (2) Masa Keanggotaan MRP adalam 5 (lima) tahun. Ayat (3) Keanggotaan dan jumlah anggota MRP sebagaimana dimaksud pada ayat (1) ditetapkan dengan Perdasus. Ayat (4) Kedudukan Keuangan MRP ditetapkan dengan Peraturan Pemerintah.

Dalam pasal 20 ayat (1), MRP mempunyai tugas dan wewenang d. Memberikan saran, pertimbangan dan persetujuan terhadap rencana perjanjian kerjasama yang dibuat oleh Pemerintah maupun Pemerintah Provinsi dengan pihak ketiga yang berlaku di Provinsi Papua khusus yang menyangkut perlindungan hak-hak orang asli Papua. e. Memperhatikan dan menyalurkan aspirasi, pengaduan masyarakat adat, umat beragama, kaum perempuan dan masyarakat pada umumnya yang menyangkut hak-hak orang asli Papua, serta memfasilitasi tindak lanjut penyelesaiannya.

Secara implisit dan eksplisit, otonomi khusus di Papua memberikan perlindungan hak-hak masyarakat adat. Hal ini diatur dalam:

\section{Pasal 43}

(1) Pemerintah Provinsi Papua wajib mengakui, menghormati, melindungi, memberdayakan dan mengembangkan hak-hak masyarakat adat dengan berpedoman pada ketentuan peraturan hukum yang berlaku;

(2) Hak-hak masyarakat adat tersebut pada ayat (1) melalui hak ulayat masyarakat hukum adat dan hak perorangan para warga masyarakat hukum adat yang bersangkutan;

(3) Pelaksanaan hak ulayat, sepanjang menurut kenyatannya masih ada, dilakukan oleh penguasa adat masyarakat hukum adat yang bersangkutan menurut ketentuan hukum adat setempat, dengan menghormati penguasaan tanah bekas hak ulayat yang diperoleh pihak-pihak secara sah menurut tata cara dan berdasarkan peraturan perundang-undangan;

(4) Penyediaan tanah ulayat dan tanah perorangan warga masyarakat hukum adat untuk keperluan apapun, dilakukan melalui musyawarah dengan masyarakat hukum adat dan warga yang bersangkutan untuk memperoleh kesepakatan mengenai penyerahan tanah yang diperlukan maupun imbalannya;

(5) Pemerintah Provinsi, Kabupaten/Kota memberikan mediasi aktif dalam usaha penyelesaian sengketa tanah ualayat dan bekas hak perorangan secara adil dan bijaksana, sehingga dapat dicapai kesepakatan yang memuaskan para pihak yang bersangkutan.

\section{Pasal 57}

(1) Pemerintah Provinsi wajib melindungi, membina dan mengembangkan kebudayaan asli Papua;

(2) Dalam melaksanakan kewajiban sebagaimana dimaksud pada ayat (1), Pemerintah Provinsi memberikan peran sebesar-besarnya kepada masyarakat termasuk lembaga swadaya masyarakat yang memenuhi syarat;

(3) Pelaksanaan kewajiban sebagaimana dimaksud pada ayat (2) disertai dengan pembiayaan; 
(4) Ketentuan lebih lanjut sebagaimana dimaksud pada ayat (2) dan ayat (3) ditentukan dengan Perdasi.

1. Peraturan Daerah Khusus Provinsi Papua Nomor 18 Tahun 2008 Tentang Perekonomian Berbasis Kerakyatan ${ }^{7}$

\section{Pasal 3}

Masyarakat adat berhak mengelola dan memanfaatkan sumber daya alam yang tersedia di wilayahnya.

\section{Pasal 4}

Pengelolaan dan pemanfaatan sumber daya alam sebagaimana dimaksud dalam pasal 3 dapat dilakukan sendiri atau bekerjasama dengan pihak lain.

2. Peraturan Daerah Khusus Provinsi Papua Nomor 20 Tahun 2008 Tentang Peradilan Adat di Papua ${ }^{8}$

\section{Pasal 2}

Peradilan Adat di Papua berdasarkan:

a. kekeluargaan;

b. musyawarah dan mufakat; dan

c. peradilan sederhana, cepat, dan biaya ringan.

\section{Pasal 3}

Peradilan Adat di Papua bertujuan:

a. sebagai wujud pengakuan pemerintah terhadap keberadaan perlindungan, penghormatan dan pembudayaan terhadap masyarakat adat Papua dan bukan Papua;

b. memperkokoh kedudukan peradilan adat; c. menjamin kepastian hukum, kemanfaatan, dan keadilan;

d. menjaga harmonisasi dan keseimbangan kosmos; dan

e. membantu pemerintah dalam penegakan hukum.

\section{Pasal 6}

Pengadilan Adat bertugas menerima dan mengurus perkara perdata adat dan perkara pidana adat.

\section{Pasal 7}

Pengadilan Adat berfungsi untuk:

a. penyelesaian perkara perdata adat dan perkara pidana adat; dan

b. melindungi hak-hak orang asli Papua dan bukan Papua.

3. Peraturan Daerah Khusus Provinsi Papua Nomor 22 Tahun 2008 Tentang Perlindungan dan Pengelolaan Sumber Daya Alam Masyarakat Adat Papua ${ }^{9}$

\section{Pasal 2}

(1) Pemerintah provinsi atau kabupaten/ kota memberikan pengakuan masyarakat hukum adat mempunyai kriteria:

a. adanya wilayah adat dengan batasbatas yang diakui oleh masyarakat hukum adat di sekitarnya;

b. adanya norma-norma hukum, struktur kelembagaan adat dan sistem kepemimpinan yang secara nyata berfungsi untuk mengatur para warga masyarakat hukum adat yang bersangkutan;

c. adanya hukum saling ketergantungan yang bersifat religi antara masyarakat

Lihat Peraturan Daerah Khusus Provinsi Papua Nomor 18 Tahun 2008 Tentang Perekonomian Berbasis Kerakyatan.

8 Lihat Peraturan Daerah Khusus Provinsi Papua Nomor 20 Tahun 2008 Tentang Peradilan Adat di Papua.

9 Lihat Peraturan Daerah Khusus Provinsi Papua Nomor 22 Tahun 2008 Tentang Perlindungan dan Pengelolaan Sumber Daya Alam Masyarakat Adat Papua. 
hukum adat dan wilayah yang menjadi hak masyarakat hukum adat.

(2) Pengakuan keberadaan masyarakat hukum adat, sebagaimana dimaksud pada ayat (1) ditetapkan dengan Peraturan Daerah Kabupaten/Kota;

(3) Pengakuan keberadaan masyarakat hukum adat yang berada pada lintas kabupaten/kota ditetapkan dengan Peraturan Daerah Provinsi atas usulan bersama Pemerintah Kabupaten/ Kota di wilayah keberadaan masyarakat hukum adat;

(4) Pengakuan sebagaimana dimaksud pada ayat (2) dan ayat (3), tidak boleh mencampuri materi atau isi sistem kepemimpinan, sistem kelembagaan, norma hukum, dan adat istiadat yang telah dimiliki oleh masing-masing masyarakat hukum adat.

4. Peraturan Daerah Khusus Provinsi Papua Nomor 23 Tahun 2008 Tentang Hak Ulayat Masyarakat Hukum Adat dan Hak Perseorangan Warga Masyarakat Hukum Adat Atas Tanah ${ }^{10}$

\section{Pasal 2}

(1) Pemerintah daerah mengakuai keberadaan hak ulayat masyarakat hukum adat dan atau hak perorangan warga masyarakat hukum adat atas tanah;

(2) Pengakuan terhadap hak ulayat masyarakat hukum adat dan atau hak perorangan warga amsyarakat hukum adat atas tanah sebagaimana dimaksud pada ayat (1) harus didasarkan atas hasil penelitian.

\section{Pasal 3}

(1) Keberadaan hak ulayat masyarakat hukum adat dan atau hak perorangan warga masyarakat hukum adat atas tanah di dasarkan asas hasil penelitian di kabupaten/kota di daerah;

(2) Penelitian untuk menentukan ada atau tidak adanya hak ulayat masyarakat hukum adat dan atau hak perorangan warga masyarakat hukum adat atas tanah dalam wilayah kabupaten/kota dilakukan oleh suatu panitia peneliti yang terdiri dari:

a. para pakar hukum adat;

b. lembaga adat/tetua adat atau penguasa adat yang berwenang atas hak ulayat dan atau hak perorangan warga masyarakat dari masyarakat hukum adat yang bersangkutan;

c. lembaga swadaya masyarakat;

d. pejabat dari Badan Pertanahan Nasional R.I.;

e. pejabat dan bagian hukum Kantor Bupati/Walikota;

f. pejabat dari instansi kehutanan dan instansi pertimbangan; dan

g. pejabat dari instansi terkait lainnya.

Perwujudan pengakuan sekaligus perlindungan masyarakat hukum adat di Indonesia sejalan dari penafsiran Jimmly Asshiddiqie: ${ }^{11}$

a. Kepada eksistensi suatu masyarakat hukum adat beserta hak-hak tradisional yang dimiliki;

10 Lihat Peraturan Daerah Khusus Provinsi Papua Nomor 23 Tahun 2008 Tentang Hak Ulayat Masyarakat Hukum Adat dan Hak Perseorangan Warga Masyarakat Hukum Adat Atas Tanah.

11 Dewi Sulastri, Pengantar Hukum Adat (Bandung: Pustaka Setia, 2015), hlm 155. 
b. Eksistensi yang diakui adalah eksistensi kesatuan-kesatuan masyarakat hukum adat. Artinya, pengakuan diberikan kepada satu per satu dari kesatuan-kesatuan tersebut sehingga masyarakat hukum adat itu haruslah tertentu;

c. Masyarakat hukum adat itu memang hidup (masih hidup);

d. Dalam lingkungannya (lebensraum) yang tertentu pula;

e. Pengakuan dan penghormatan itu diberikan tanpa mengabaikan ukuranukuran kelayakan bagi kemanusiaan sesuai dengan tingkat perkembangan keberadaan bangsa. Misalnya, tradisitradisi tertentu yang memang tidak layak lagi dipertahankan, maka tidak boleh dibiarkan tidak mengikuti arus kemajuan peradaban hanya karena alasan sentimentil.

f. Pengakuan dan penghormatan itu tidak boleh mengurangi makna Indonesia sebagai suatu negara yang berbentuk Negara Kesatuan Republik Indonesia.

Dari berbagai peraturan perundangundangan yang telah dikeluarkan, mulai dari Undang-Undang Nomor 21 Tahun 2001 tentang Otonomi Khusus di Papua, Perdasus Provinsi Papua Nomor 18 Tahun 2008 tentang Perekonomian Berbasis Kerakyatan, Perdasus Provinsi Papua Nomor 20 Tahun 2008 tentang Peradilan Adat di Papua, Perdasus Provinsi Papua Nomor 22 Tahun 2008 tentang Perlindungan dan Pengelolaan Sumber Daya Alam Masyarakat Hukum Adat Papua dan Perdasus Provinsi Papua Nomor 23 Tahun 2008 tentang Hak Ulayat Masyarakat Hukum Adat dan Hak Perorangan Warga Masyarakat Hukum Adat Atas Tanah yang ditegaskan dalam pasalpasalnya, secara implisit dan eksplisit telah mengatur perlindungan hukum pertanahan adat di Papua, dalam konteks negara kesejahteraan. Namun demikian kendala dalam implementasi peraturan perundangundangan tersebut tidak dapat dipungkiri. Aspek-aspek seperti keterbatasan sumber daya manusia warga masyarakat adat di Papua serta sarana dan prasarana yang masih sangat minim di Papua merupakan fenomena umum yang masih sulit ditanggulangi. Di samping itu, sosialisasi peraturan perundang-undangan tersebut serta keseriusan dari pemerintah daerah, MRP dan Dewan Perwakilan Rakyat Papua (DPRP) juga terkendala. Yang juga mengganjal dari implementasi peraturan perundang-undangan tersebut adalah belum adanya penyelarasan persepsi diantara pihakpihak terkait, serta adanya pemanfaatan pertanahan adat untuk kegiatan eksploitasi tambang dan perkebunan.

Sebagai upaya mendukung pembangunan hukum, hukum adat dalam konteks tertentu ditempatkan pada posisi penting dalam suatu proses pembangunan hukum nasional. Sehubungan dengan hal itu, keselarasan peran hukum adat dalam pembentukan, pembinaan dan pembangunan hukum nasional, tentu memperhatikan nilai-nilai sosial dan budaya dari hukum adat tersebut, termasuk peranannya masing-masing, yaitu: ${ }^{12}$

1. Nilai-nilai yang harus dipelihara dan diperkuat untuk menunjang pembangunan (hukum);

12 Soerjono Soekanto, Beberapa Permasalahan Hukum dalam Kerangka Pembangunan di Indonesia (Jakarta: UI Pers, 1976), hlm 200. 
2. Nilai-nilai yang menunjang pembangunan (hukum) yang disesuaikan atau
diharmonisasi dengan proses
pembangunan;

3. Nilai-nilai yang menghambat pembangunan (hukum), tetapi secara berangsur-angsur akan berubah karena faktor-faktor lain dalam pembangunan;

4. Nilai-nilai yang secara definitif menghambat pembangunan (hukum) harus segera dihapuskan.

Pelaksanaan otonomi khusus di Papua, dalam aspek di bidang kebudayaan dan adat setidaknya sampai tahun 2012 kondisinya banyak dipersoalkan: ${ }^{13}$

1. Belum secara sungguh-sungguh dan implementatif Pemerintah

Provinsi Papua dan Pemerintah Pusat mengakui, menghormati, melindungi, memberdayakan dan mengembangkan hak-hak masyarakat adat dengan berpedoman pada ketentuan peraturan hukum yang berlaku;

2. Hak-hak masyarakat adat yang meliputi hak ulayat masyarakat hukum adat dan hak perorangan para warga masyarakat hukum adat yang bersangkutan tidak diakui, tidak dihormati dan tidak dilindungi sebagai suatu kewajiban oleh Pemerintah Provinsi yang ada;

3. Tidak adanya pelaksanaan hak ulayat yang dilakukan oleh penguasa adat yang bersangkutan menurut ketentuan hukum adat setempat, karena penghormatan dan pengakuan serta perlindungan dari pihak Pemerintah dan pihak ketiga, sebaliknya, mereka berstrategi untuk menghilangkan atau mengambil alih hak-hak masyarakat hukum adatnya;

4. Terjadinya menipulasi dan spekulasi politik terhadap tanah ulayat dan tanah perorangan warga masyarakat hukum adat untuk berbagai keperluan dan pendekatan yang dilakukan melalui musyawarah dengan masyarakat hukum adat dan warga yang bersangkutan untuk memperoleh kesepakatan mengenai penyerahan tanah yang diperlukan maupun imbalannya merupakan upaya terselubung dari pertimbangan lain yang biasanya tidak diungkapkan dalam musyawarah yang dimaksudkan;

5. Belum adanya pemberian mediasi aktif dari Pemerintah Provinsi dalam usaha penyelesaian sengketa tanah ulayat dan bekas hak perorangan secara adil dan bijaksana, sehingga seringkali terjadi sengketa tanah secara terus-menerus;

6. Belum adanya perlindungan afirmatif terhadap hak kekayaan intelektual Orang Asli Papua dari Pemerintah Provinsi;

7. Adanya intervensi secara sengaja terhadap lembaga adat asli Papua dengan cara membentuk Lembaga Adat "boneka" bikinan Pemerintah Pusat;

8. Adanya sifat provokatif dalam masyarakat hukum adat oleh aparat pemerintah Kampung, sehingga kelestarian nilai budaya Papua terkikis dari waktu ke waktu;

9. Keberadaan lembaga Majelis Rakyat Papua Provinsi Papua Barat tidak berasaskan kebijakan Undang-Undang Otonomi Khusus dan menimbulkan banyak polemik.

3 Laporan Hasil Evaluasi Otonomi Khusus Papua dan Papua Barat, Implementasi Otsus Papua dan Papua Barat Dalam Pengalaman Empiris Orang Asli Papua (Jayapura: MRP, 2013), hlm 25-26. 
Otonomi khusus di Papua yang terpusat pada tingkat provinsi, bukan didesentralisasikan pada kabupaten/kota, ternyata juga menjadikan tidak aplikatifnya semangat, cita-cita dan upaya untuk melakukan perlindungan pertanahan adat di Papua. Konflik kepentingan antara Pemerintah Provinsi dengan masyarakat hukum adat di Papua berkali-kali terjadi. Sehingga upaya untuk menuju masyarakat sejahtera di Papua masih harus diupayakan meskipun berbagai peraturan perundang-undangan sudah diberlakukan.

Di lingkungan masyarakat hukum adat Papua, sebagaimana hasil penelitian oleh $A$. Bondermaker, sebelum masuk menjadi Negara Kesatuan Republik Indonesia, menyimpulkan kondisi umum sebagai berikut: ${ }^{14}$

a. Tanah ulayat adalah tumpah darah;

b. Tanah ulayat tidak boleh dimiliki oleh masyarakat di luar kesatuan masyarakat hukum adat dengan hak milik, tetapi hanya hak pakai;

c. Orang luar boleh menggunakan tanah dalam suatu wilayah masyarakat hukum adat, bila ia pergi, tanah tetap dikembalikan kepada masyarakat adat, selanjutnya oleh pemimpin masyarakat hukum adat diatur lagi peruntukannya kepada anggota lain;

d. Anggota masyarakat hukum adat sendiri hanya boleh mempunyai hak pakai, sehingga ia tidak berhak untuk melakukan sesuatu perbuatan atas tanah tersebut.

Beberapa perundang-undangan lainnya yang memberikan perlindungan masyarakat hukum adat, diantaranya Undang-undang
Nomor 41 Tahun 1999 Tentang Kehutanan. Pada Pasal 67 ayat (1) dengan memenuhi unsur-unsur:

- Masyarakatnya masih dalam bentuk paguyuban (rechtgemenschaap);

- Ada kelembagaan dalam bentuk perangkat penguasaan adatnya;

- Ada wilayah hukum adat yang jelas;

- Ada pranata dan perangkat hukum khususnya peradilan adat yang masih ditaati;

- Mengadakan pemungutan hasil hutan di wilayah hutan sekitarnya untuk memenuhi kebutuhan hidupnya sehari-hari.

Dengan berbagai keterbatasannya, perkembangan masyarakat hukum adat di Papua dalam pengelolaan pertanahan, ternyata tidak berubah. Sebagai fenomena umum, dari banyak penegasan yang dikemukakan berbagai pakar, di luar wilayah perkotaan dan tanah-tanah yang dikuasai negara (instansi pemerintah), dan oleh sementara pihak yang lain, merupakan tanah ulayat yang dimiliki oleh masyarakat hukum adat. Pada saat yang sama, negara yang mengeluarkan produk peraturan perundangundangan tertentu, misalnya UndangUndang Kehutanan mempersyaratkan sesuai administrasi pada era modern. Sehingga perlindungan pertanahan adat di Papua menjadi mengambang.

\section{Negara Kesejahteraan}

Otonomi khusus di Papua, sebagai kebijakan atau praktik hukum Negara Kesatuan Republik Indonesia (NKRI), dimaknai sebagai upaya menegakkan NKRI dalam artian Papua

14 Rosnidar Sembiring, Hukum Pertanahan Adat (Jakarta: Rajawali Pers, 2017), hlm. 73. 
tidak melepaskan diri dari NKRI dan sekaligus memberikan berbagai kebijakan yang komprehensif, termasuk menggelontorkan dana dengan jumlah yang sangat besar, dibandingkan dana yang diberikan pada provinsi yang lain. Sesuai situasi dan kondisi, kenyataannya Papua masih banyak tertinggal dibandingkan provinsi lainnya. Masyarakat hukum adat di Papua masih mendominasi dan secara mendasar terkendala dengan berbagai keterbatasan. Pemerintah, baik pusat dan daerah memiliki tanggung jawab untuk menyelesaikan berbagai persoalan tersebut.

Negara yang berusaha menyelenggarakan sebaik-baiknya kesejahteraan umum yang meliputi segala individu maupun masyarakat, dinamakan "Negara Kesejahteraan" (Welfare State). Kesejahteraan umum ini dapat dirumuskan sebagai tersedianya dengan cukup segala sarana dan fasilitas yang diperlukan untuk memungkinkan semua warga negara mencukupi segenap kebutuhannya yang pokok baik fisik maupun rohaniah. Di dalam negara modern, tujuan negara tidak terbatas pada pemeliharaan keamanan dan ketertiban saja (internal order) dimana tiada lain daripada suatu alat penertiban semata-mata yang dikenal dengan sebutan "Negara Penjaga Malam" (machtwacherstaat), melainkan mempunyai tujuan yang lebih luas dan mulia, yaitu tercapainya kesejahteraan bagi semua warga masyarakat dan tingkat peradaban yang lebih tinggi. ${ }^{15}$
Sedangkan pakar sosial Sugeng Pujileksono ${ }^{16}$ yang mengutip dari para pakar tentang negara kesejahteraan (welfare state) diantaranya menyatakan ciri utama negara kesejahteraan adalah munculnya kewajiban pemerintah untuk mewujudkan kesejahteraan umum bagi rakyatnya. Dengan kata lain ajaran negara kesejahteraan merupakan bentuk peralihan prinsip staatson thoding (pembatasan peran negara dan pemerintah untuk mencapai kehidupan ekonomi dan sosial masyarakat) menjadi staatesbemoerenis yang menghendaki negara dan pemerintah tersebut aktif dalam kehidupan ekonomi dan sosial, sebagai langkah untuk mewujudkan kesejahteraan umum, disamping menjalankan ketertiban dan keamanan. Menurut Preison, pola-pola keterlibatan negara mencakup negara sebagai pemilik, negara sebagai pemilik dan produsen, negara sebagai majikan, negara sebagai regulator, negara sebagai redistributor, negara sebagai pembuat kebijakan ekonomi.

Suatu pertimbangan hukum masyarakat hukum adat dalam negara kesejahteraan di Papua, telah dan terus diwujudkan melalui pendekatan hukum dan peraturan perundangundangan lainnya. Upaya ini telah diantisipasi dan dilaksanakan secara serius, dan konsisten oleh penyelenggara negara. Terkini, pada pemerintahan Presiden Joko Widodo telah melakukan serangkaian kebijakan dan program.

15 Laporan Akhir Tim Pengkajian Hukum Tentang Pengelolaan Tanah Negara Bagi Kesejahtaraan Rakyat (Jakarta: BPHN Kemenkumham, 2012), hlm 128.

16 Sugeng Pujileksono, Perundang-undangan Sosial dan Pekerjaan Sosial Perspektif Pemenuhan Keadilan dan Kesejahteraan Sosial Masyarakat (Malang: Setara Pers, 2016), hlm 69-70. ${ }^{34} \quad$ United States Departement of State, Bureau of Intelligence and Research, "Limits in the Seas No. 101 Fiji's Maritime Claims," United States Departement of State, https://2009-2017.state.gov/documents/organization/58567.pdf. (diakses 30 November 2018). 
Percepatan pembangunan Provinsi Papua dan Papua Barat mulai tahun 2015 dilakukan dengan menggunakan pendekatan berbasis wilayah adat, sebagaimana yang diuraikan secara rinci dalam Buku III Bab II Arah Pengembangan Wilayah Papua RPJMN 2015-2019. Pendekatan pembangunan berbasis wilayah adat digunakan untuk memudahkan intervensi pembangunan, dengan mengelompokkan wilayah Papua berdasarkan kedekatan kondisi geografis, adat, dan budaya. Kegiatan Temu Kawasan Adat dilaksanakan diseluruh 5 wilayah adat (di salah satu Kabupaten Provinsi Papua, yaitu wilayah adat Saireri (Biak), Mamta (Sarmi), Me Pego (Mimika), La Pago (Wamena), dan Aniem-Ha (Merauke) pada tanggal 10-25 Maret 2015. ${ }^{17}$

Upaya mewujudkan perlindungan hukum pertanahan adat di Papua sekaligus menuju negara kesejahteraan, sudah barang tentu telah berlangsung lama, paling tidak berkenaan dikeluarkannya Undang-undang Nomor 21 Tahun 2001 Tentang Otonomi Khusus di Papua, untuk mewujudkan kesejahteraan masyarakat Papua, serangkaian pembangunan ekonomidan infrastrukturtelah dan terus dilakukan. Dalam pembangunan ekonomi misalnya, pengelolaan tambang tembaga dan kemudian emas di Timika, telah berlangsung lebih dari 30 tahun. Persoalan tanah adat yang digarap atau dikerjakan oleh PT Freeport, seringkali menjadi isu politik nasional yang pada gilirannya akan berpotensi mengecilkan perlindungan tanah adat di Papua. Walaupun dalam perkembangan terakhir, hak-hak masyarakat adat di Papua telah ditanggung dengan pemilikan saham PT Freeport sebesar 10\% dikelola oleh Pemda Provinsi Papua. Problematika perlindungan tanah adat di Papua, juga beririsan dengan pembukaan hutan untuk perkebunan sawit yang pada setiap perusahaan memerlukan ratusan ribu hektar. Belum lagi pembangunan infrastruktur berupa jalan yang secara masif dikerjakan pada pemerintahan Presiden Joko Widodo sekarang.

Aspek-aspek antara kelestarian lingkungan yang berhadapan dengan upaya mewujudkan kesejahteraan masyarakat, juga diwarnai oleh isu-isu serius dengan penebangan hutan secara illegal dari kawasan hutan di Papua. Sehingga, pola-pola keseimbangan antara pemanfaatan tata ruang untuk masyarakat hukum adat Papua dan untuk menuju negara kesejahteraan tidak boleh dilanggar oleh pihak di luar masyarakat hukum adat.

Menurut Suhartini, masyarakat asli di suatu daerah memiliki cara pandang dan wawasan terkait lingkungan mereka, cara pandang serta konsep itulah yang dapat kita artikan sebagai bagian dari kearifan lokal. Kearifan lokal mempunyai cakupan yang lebih luas daripada sekedar pengetahuan tradisional. Kearifan lokal merupakan perwujudan implementasi Peraturan Daerah Khusus Provinsi Papua Nomor 22 Tahun 2008 Tentang Perlindungan dan Pengelolaan Sumber Daya Alam Masyarakat Adat Papua dan pengejawantahan serta bentuk pengetahuan tradisional yang dipakai oleh manusia atau masyarakat yang berinteraksi dengan alam sekitarnya, sehingga kearifan lokal merupakan pengetahuan kebudayaan

17 Laporan Akhir Koordinasi Strategis Asistensi Percepatan pembangunan Provinsi Papua dan Papua Barat (Jakarta: Direktorat Kawasan Khusus dan Daerah Tertinggal Kementerian Pembangunan Nasional/Bappenas, 2015). 
yang dimiliki kelompok masyarakat tertentu mencakup model-model pengelolaan sumber daya alam secara lestari, termasuk bagaimana menjaga hubungan dengan alam melalui pemanfaatan yang bijaksana dan bertanggung jawab. ${ }^{18}$

Problematika dan kendala dalam memberikan perlindungan hukum terhadap pertanahan adat di Papua, yaitu: ${ }^{19}$

a. Sampai munculnya Peraturan Menteri Agraria/Kepala Badan Pertanahan Nasional Nomor 5 Tahun 1999 tentang Pedoman Penyelesaian Masalah Hak Ulayat Masyarakat Hukum Adat. Akibat ketiadaan pedoman penentuan hak ulayat, maka sejak UUPA diundangkan, yang kemudian diikuti terbitnya Undang-Undang Nomor 5 Tahun 1967 yang berlaku sejak 14 Mei 1967 tentang Ketentuan-ketentuan Pokok Kehutanan, hingga Undang-undang Nomor 41 Tahun 1999 tentang Kehutanan, sudah tidak terhitung lagi berapa hektar hutan adat yang sudah beralih fungsi menjadi lahan konsesi perusahaan, pembangunan dan perkebunan, serta berapa jumlah konflik antara masyarakat hukum adat dengan korporasi.

b. Derasnya deforestasi hutan adat agak mereda sejak ada putusan Mahkamah Konstitusi Nomor 35/PUU-X/2012 tanggal 16 Mei 2013 yang menyatakan bahwa hutan adat bukan lagi bagian hutan negara. Jadi kalau dihitung sudah lebih dari 16 tahun sejak Mei 1967 sampai dengan Mei
2013 masyarakat hukum adat kehilangan hutan adatnya. Sampai sekarangpun untuk memperoleh penetapan hutan adat juga bukan hal yang mudah, sekalipun sudah difasilitasi oleh Kementerian Kehutanan, karena kunci pokok ada di pemerintah kabupaten, apakah mau atau tidak membuat Perda atau Surat Keputusan Bupati tentang eksistensi masyarakat hukum adat sebagai salah satu syarat penetapan hutan adat.

c. Kendatipun sudah ada Putusan Mahkamah Konstitusi Nomor 35/PUU-X/2012 Tentang Uji Materi Undang-undang Nomor 41 Tahun 1999 Tentang Kehutanan, menentukan hutan adat bukan lagi hutan negara dan Putusan Mahkamah Konstitusi Nomor 55/ PPP-VII-1010 tentang Uji Materi Undangundang Nomor 18 Tahun 2004 tentang Perkebunan yang membatalkan Pasal 21 dan Pasal 47 ayat (1) dan ayat (2) yang mengkriminalisasi masyarakat hukum adat yang mempertanahkan tanah adatnya dari perusahaan perkebunan, bersifat final dan mengikat (binding), masih ada beberapa peraturan perundang-undangan yang tidak memberdayakan hukum tak tertulis maupun subyeknya, yaitu masyarakat hukum adat, semisal Undangundang Nomor 4 Tahun 2009 tentang Pertambangan Mineral dan Batubara, khususnya Pasal 136 ayat (2) dan Pasal 162 yang berpotensi mengkriminalisasi, di antaranya masyarakat hukum adat

18 Suhartini, Kearifan Lokal dan Konservasi Keanekaragaman Hayati, (Yogyakarta: UGM, 2009), hlm. 44 dalam Kristiyanto, Eko Noer, "Implementasi Kearifan Lokal Sunda Dalam Penataan Ruang Menurut Undang-undang Nomor 26 Tahun 2007 Tentang Penataan Ruang, Studi di Bandung Jawa Barat", Jurnal Penelitian De Jure Volume 18 Nomor 2 (Juni 2018).

19 I Nyoman Nurjaya, "Pengelolaan Sumber Daya Alam Berbasis Masyarakat Hukum Adat perspektif Antropologi Hukum", (makalah disampaikan pada Seminar Nasional Pemberdayaan Hukum Tidak Tertulis Dalam Grand Design Pembangunan Hukum Nasional, BPHN Kementerian Hukum dan HAM, 27 Juni 2019). 
yang mempertahankan tanahnya dari perusahaan pertambangan.

Pendapat yang hampir senada dikemukakan oleh pakar hukum lainnya. Sukirno mengemukakan bahwa jika dicermati secara seksama, selama kurun waktu lebih dari lima dasawarsa terakhir ini, peraturan perundang-undangan produk lembaga legislatif bersama eksekutif khususnya yang mengatur sumber daya alam (tanah, hutan, pertambangan dan mineral, minyak dan gas bumi, sumber daya air, keanekaraman hayati, dan sumber daya perikanan) cenderung memperlihatkan karakteristik hukum yang bercorak sentralistik, ekspoitatif (use oriented), berpihak kepada pemodal besar (high capital oriented), dengan manajemen sektoral, menutup ruang bagi transparansi dan partisipasi publik, serta mengabaikan hak-hak masyarakat hukum adat. ${ }^{20}$ Karena itu, panutan ideologi sentralisme hukum dalam pengaturan mengenai sumber daya alam dan lingkungan hidup seperti dideskripsikan di atas paling tidak telah menimbulkan 4 (empat) implikasi krusial, yaitu:

1. Pengabaian atas prinsip-prinsip keadilan, demokrasi dan keberlanjutan ekologi, partisipasi publik dan prinsip informalconsent, karena hak hidup, politik, ekonomi dan sosial masyarakat hukum adat secara sadar diabaikan, digusur, tidak diberdayakan dan tidak diberi ruang dalam kehidupan hukum di negeri ini.

2. Secara tidak langsung, produk kebijakan dan hukum negara menjadi sumber penyebab kerusakan dan degradasi sumber daya alam, karena orientasi pengaturannya lebih diarahkan sematamata untuk mengejar target pertumbuhan ekonomi dengan dalih meningkatkan pendapatan dan devisa negara (state revenue) dengan mengeksploitasi sumber daya alam.

3. Menimbulkan marjinalisasi dan perusakan tatanan kehidupan sosial dan budaya masyarakat hukum adat, karena pranata hukum dibangun secara sentralistik dan represif serta diseragamkan seperti yang dikehendaki pemerintah dengan berorientasi lebih pada peningkatan pembangunan ekonomi.

4. Terjadi proses kriminalisasi, viktimisasi dan dehumanisasi terhadap eksistensi masyarakat hukum adat dalam bentuk pemberian stigma atau label negatif, seperti masyarakat yang primitif, masyarakat terasing, masyarakat tradisional yang tidak rasional, perusak hutan, pencuri hasil hutan, peladang liar, pembakar hutan atau penambang liar, yang tidak kooperatif dan menghambat pelaksanaan pembangunan. Intinya, terjadi pemberian stigma kriminologis, cenderung mengabaikan dan mendistkreditkan eksistensi masyarakat hukum adat di daerah dengan memberlakukan political of legal plurality ignorance.

Keberhasilan dalam memberikan perlindungan pertanahan adat di Papua, adalah untuk mensejahterakan rakyat Papua

20 Sukirno, "Politik Hukum Pemberdayaan Hukum Tidak Tertulis dalam Peraturan Perundang-undangan Sejak Masa Penjajahan Belanda hingga Sekarang", (makalah disampaikan pada Seminar Nasional Pemberdayaan Hukum Tidak Tertulis Dalam Grand Design Pembangunan Hukum Nasional, BPHN Kementerian Hukum dan HAM, 27 Juni 2019). 
yang berjaya. ${ }^{21}$ Frame pembangunan politik dan kemanusiaan secara bersaudara diarahkan kepada 9 (sembilan) langkah konkret:

Pertama, penanganan masalah Papua harus digeser dari pendekatan keamanan ke pendekatan kesejahteraan. Mendengarkan dan dialog adalah pintu masuk utamanya. Dengan kunci penghormatan terhadap hak asasi manusia.

Kedua, agar langkah pertama lebih bisa dioperasionalkan di lapangan, unit kerja bekerja langsung di bawah Presiden dan Wakil Presiden.

Ketiga, perlu kiranya dipertimbangkan pertemuan antara Presiden dan pimpinan MPR, DPR Papua, DPR Papua Barat untuk membicarakan masalah demilitarisasi dan pemberian keadilan kepada para keluarga korban pelanggaran HAM.

Keempat, diperlukan politik pintu terbuka kepada tokoh-tokoh dan kelompokkelompok yang selama ini belum puas atas kerja pemerintah di Papua, khususnya kepada mereka yang masih menuntut kemerdekaan.

Kelima, perlu ditempuh langkah affirmative policy dalam bidang pertahanan, dimana para perusahaan besar dan MNC-TNC tidak diperbolehkan memiliki tanah secara luas tanpa menjadikan penduduk setempat sebagai partner dalam joint entrepreneurship.

Keenam, perlu dirancang sistem pendidikan yang cocok dengan karakter pembangunan masyarakat Papua. Tumpuan pendidikan pada peningkatan ketrampilan baik pada bidang kelautan, kehutanan, pertanian, industri ringan maupun pertambangan.

Ketujuh, diperlukan satu program jangka pendek dan jangka menengah untuk meningkatkan mutu pelayanan kesehatan dalam bentuk mendirikan sekolah perawat, bidan serta dokter.

Kedelapan, diperlukan secara mendesak peningkatan kemampuan pemerintah daerah. Langkah ini ditujukan untuk meningkatkan kapasitas pemerintah dalam mengelola dan menjawab tantangan-tantangan baru dan bebas korupsi. Juga diperlukan peningkatan tata kelola pemerintahan yang baik dan bersih agar masyarakat bisa mempercayai pemerintah.

Kesembilan, untuk meningkatkan pembangunan infrastruktur dasar dan yang bernilai ekonomi tinggi, segenap kementerian dan lembaga harus mendukung unit dengan program yang jelas.

Kendala yang selalu terjadi pada warga masyarakat di Indonesia tentang keberlakuan berbagai peraturan perundang-undangan, termasuk di Papua, tidak lain sosialisasi dan konsistensi pemerintah kurang dan nyaris tidak ada.

\section{Penutup}

Kebijakan negara dalam mewujudkan perlindungan hukum pertanahan di Papua, sudah cukup memadai diatur mulai dari UUD 1945 sampai dengan berbagai peraturan perundang-undangan yang berlaku. Dengan Undang-undang Nomor 21 Tahun 2001 tentang Otonomi Khusus di Papua, secara eksplisit perlindungan hukum masyarakat adat di Papua, lebih dimaksimalkan dan juga diarahkan untuk menyejahterakan masyarakat di Papua.

21 Wawan H. Purwanto, Papua Meradang, Siapa Berani (Jakarta: CMB Press, 2013), hlm. 279-281. 
Sebagai peraturan pelaksanaan UndangUndang Otonomi Khusus di Papua, beberapa Peraturan Daerah Provinsi dan Peraturan Daerah Khusus juga telah dikeluarkan dan dilaksanakan untukmewujudkan perlindungan hukum masyarakat hukum adat di Papua. Yang masih harus mendapat perhatian yang sangat serius ialah sosialisasi terhadap berbagai Peraturan Daerah Provinsi dan Peraturan Daerah Khusus Papua, masih jauh dari yang diharapkan. Problematika yang lainnya, peraturan perundang-undangan lainnya, seperti Undang-undang Nomor 41 Tahun 1999 tentang Kehutanan dan Undang-undang Nomor 4 Tahun 2009 tentang Pertambangan Mineral dan Batubara yang sentralistik, justru merugikan masyarakat hukum adat di Papua. Di samping itu, persamaan persepsi di antara sebagian masyarakat hukum adat Papua dengan elite pemerintahan Provinsi Papua dan Pemerintah Pusat belum sepenuhnya berlangsung baik dan lancar.

Harus diakui bahwa terdapat keselarasan antara menuju dan mewujudkan perlindungan hukum pertanahan adat di Papua, dengan berbagai prinsip negara kesejahteraan. Namun demikian, masih banyak kendala yang sangat berat yang harus dilaksanakan bersama untuk mencapai cita-cita yang luhur dan mulia tersebut.

Konsistensi pemerintah dan negara dalam memberikan dan mewujudkan perlindungan pertanahan adat di Papua harus selaras dengan cita-cita dan semangat negara kesejahteraan. Sosialisasi dan sekaligus pelaksanaan dari Peraturan Daerah Khusus dan Peraturan Daerah Provinsi yang memberikan perlindungan pertanahan adat di Papua, harus direalisasikan secara cepat dan meluas terhadap seluruh masyarakat hukum adat di Papua. Harmonisasi Undang-Undang Nomor 21 Tahun 2001 tentang Otonomi Khusus di Papua terhadap Undang-Undang Nomor 41 Tahun 1999 tentang Kehutanan dan Undang-undang Nomor 4 Tahun 2009 tentang Pertambangan Mineral dan Batubara, sangat diperlukan secara mendesak. Sehingga tidak ada kesan pemerintah pusat bersifat ambigu dalam melaksanakan hukum perlindungan pertanahan adat di Papua. Persamaan persepsi antara para elite politik dan pemerintah daerah dengan para pemuka adat di Papua untuk mewujudkan kesejahteraan warga masyarakat Papua adalah pilihan terbaik.

\section{Daftar Pustaka}

\section{Buku}

Laporan Hasil Evaluasi Otonomi Khusus Papua dan Papua Barat, Implementasi Otsus Papua dan Papua Barat dalam Pengalaman Empiris Orang Asli Papua (Jayapura: MRP, 2013).

Laporan Akhir Koordinasi Strategis Asistensi Percepatan pembangunan Provinsi Papua dan Papua Barat (Jakarta: Direktorat Kawasan Khusus dan Daerah Tertinggal Kementerian Pembangunan Nasional/Bappenas, 2015).

Laporan Akhir Tim Pengkajian Hukum Tentang Pengelolaan Tanah Negara Bagi Kesejahtaraan Rakyat (Jakarta: BPHN Kemenkumham, 2012). Majelis Rakyat Papua (Jayapura, 2016).

Nuralam, H., Kesejahteraan Yang Tersandera: Implementasi Desentralisasi Fiskal dan Otonomi Khusus di Papua (Yogyakarta: Sonjana, 2011).

Pujileksono, Sugeng, Perundang-undangan Sosial dan Pekerjaan Sosial Perspektif Pemenuhan Keadilan dan Kesejahteraan Sosial Masyarakat (Malang: Setara Pers, 2016).

Purwanto, Wawan H., Papua Meradang, Siapa Berani (Jakarta: CMB Press, 2013).

Sembiring, Rosnidar, Hukum Pertanahan Adat (Jakarta: Rajawali Pers, 2017).

Soekanto, Soerjono, Beberapa Permasalahan Hukum dalam Kerangka Pembangunan di Indonesia (Jakarta: UI Pers, 1976). 
Soekanto, Soerjono dan Sri Mamudji, Penelitian Hukum Normatif: Suatu Tinjauan Singkat (Jakarta: Raja Grafindo Persada, 2001).

Sulastri, Dewi, Pengantar Hukum Adat (Bandung: Pustaka Setia, 2015).

Wanggai, Velik V, New Deal for Papua: Menata Kembali Papua Dengan Hati (Jakarta: Indonesia Press dan The Irian Institute, 2009).

\section{Makalah/Jurnal/ Artikel/Hasil Seminar}

Kristiyanto, Eko Noer, "Implementasi Kearifan Lokal Sunda Dalam Penataan Ruang Menurut Undang-Undang Nomor 26 Tahun 2007 Tentang Penataan Ruang, Studi di Bandung Jawa Barat", Jurnal Penelitian De Jure Volume 18 Nomor 2 (Juni 2018).

Nurjaya, I Nyoman, "Pengelolaan Sumber Daya Alam Berbasis Masyarakat Hukum Adat perspektif Antropologi Hukum", (makalah disampaikan pada Seminar Nasional Pemberdayaan Hukum Tidak Tertulis Dalam Grand Design Pembangunan Hukum Nasional, BPHN Kementerian Hukum dan HAM, 27 Juni 2019).

Sukirno, "Politik Hukum Pemberdayaan Hukum Tidak Tertulis dalam Peraturan Perundangundangan Sejak Masa Penjajahan Belanda hingga Sekarang", (makalah disampaikan pada Seminar Nasional Pemberdayaan Hukum Tidak Tertulis Dalam Grand Design Pembangunan Hukum Nasional, BPHN Kementerian Hukum dan HAM, 27 Juni 2019).

\section{Peraturan}

Undang-Undang Dasar 1945

Undang-undang Nomor 41 Tahun 1999 tentang Kehutanan.

Undang-Undang Nomor 21 Tahun 2001 tentang Otonomi Khusus Papua

Undang-Undang Nomor 6 Tahun 2012 tentang Desa.

Peraturan Daerah Provinsi Papua Nomor 16 Tahun 2008 tentang Perlindungan dan Pembinaan Kebudayaan Asli Papua.

Peraturan Daerah Khusus Provinsi Papua Nomor 18 Tahun 2008 tentang Perekonomian Berbasis Kerakyatan.

Peraturan Daerah Khusus Provinsi Papua Nomor 20 Tahun 2008 tentang Peradilan Adat di Papua.

Peraturan Daerah Khusus Provinsi Papua Nomor 22 Tahun 2008 tentang Perlindungan dan Pengelolaan Sumber Daya Alam Masyarakat Hukum Adat Papua. 